Fecha de recepción: julio 2014

Fecha de aceptación: marzo 2015

Versión final: julio 2015

\section{An exploratory study of fashion social customer service}

\author{
Karina Nobbs * and Gretchen Harnick **
}

\begin{abstract}
Summary: Digital technology has changed the way fashion brands communicate with consumers and market their products. Moreover, the rise of social media platforms in recent years has helped to make this dialogue more appealing, inviting millions of new consumers to engage with brands on a personal level (PEW, 2013). A recent Drapers (2013) report on innovation in fashion retail suggests that $52 \%$ of fashion businesses are using social media for customer interaction and relationship management. The aim of this research is to explore the use of social media for customer service. Firstly the study will identify the reasons why fashion brands are using this platform and secondly it will examine how brands are using it. Companies who are leading in this space are predominately American or Pure Play. To illustrate Warby Parker the innovative eyewear brand has been responding to customer service issues via You Tube clips which are now getting over 100 views (Mashable, 2013). One of the major challenges but also opportunities is that consumers use social media to complain about customer service issues (Brandwatch, 2013). ASOS has dedicated Facebook and Twitter 'Here to Help' accounts which allow their other social channels to be used for PR and communication purposes thereby minimizing negative content on them (Bauer, 2013). Conversocial (2013) is a specialist social media customer service provider which has calculated that effective monitoring and reaction to social customer service can have a direct return on investment. Due to an absence of accepted theoretical frameworks this study adopts a qualitative approach, using secondary research, content analysis of social media platforms and in-depth interviews with fashion brand representatives in order to meet the research aim.
\end{abstract}

Keywords: social media - customer service - technology - fashion - retail - digital business model - differentiation - brand strategy - communication.

[Summaries in spanish and portuguese at pages 261-262]

${ }^{*}$ Senior Lecturer in Fashion Branding and Retail Strategy, London College of Fashion.

${ }^{(*)}$ Assistant Professor Fashion Marketing, Parsons, The New School for Design. 


\section{Introduction}

Digital technology has changed the way fashion brands communicate with consumers and market their products. Moreover, the rise of social media platforms in recent years has helped to make this dialogue more appealing, inviting millions of new consumers to engage with brands on a personal level. A recent Drapers (2013) report on innovation in fashion retail suggests that $52 \%$ of fashion businesses are using social media for customer interaction and relationship management. The aim of this research is to explore the use of social media for customer service within the fashion sector. Firstly, the study will identify the definition and types of social customer service. Then it will address the benefits and challenges of utilizing digital means for this kind of communication between brands and consumers. The methodology adopted for this project mixes secondary research in the form of three case studies with content analysis of each of the brand's social media platforms. The case study companies are Burberry, Modcloth, and Next. These were chosen as they each are mentioned frequently in trade press and market reports regarding social customer service.

It is important first to outline the rationale for the research project which has both an academic and a commercial perspective. There is a dearth of empirical research on social media marketing, particularly which is applied to the fashion sector. Furthermore, the journal articles which do exist date quickly and tend to look at the topic from a consumer perspective rather than a business and management viewpoint. This paper aims to contribute to academic debate on the value of social media marketing and customer service through the inclusion of primary research within an applied context. It is anticipated that the content of the research will be of interest to academics looking at emerging models of brand communication and customer service, and industry professionals and practitioners in the field of social media management and marketing.

The commercial rationale for this research is threefold, and is firstly related to the notion that fashion brands are increasingly investing in social media from a strategic perspective. This is evidenced by 'social media manager' positions being created within marketing or retail departments. Secondly, when looking at social media platforms, fashion brands now have multiple accounts which can be business function or product category specific. For example, ASOS has dedicated Facebook and Twitter 'Here to Help' accounts which allow their other social channels to be used for PR and communication purposes thereby minimizing negative content on them (Bauer, 2013). The final part of the industry rationale is that there are new businesses emerging whose business models are concentrated on the management and analysis of social customer service. To illustrate, Conversocial is the leading brand in the marketplace; they describe themselves as a specialist social media customer service provider, and postulate that effective monitoring and reaction to social customer service can have a considerable direct return on investment. In sum, social customer service (SCS) is an exciting and innovative phenomenon that requires further academic and industry exploration. 


\section{Definitions and background to SCS}

This section of the paper reviews the limited literature on the topic and begins by defining and characterizing SCS by exploring its evolution. Interestingly retail consumers prefer SCS, with $45 \%$ having contacted a company for support through social media, this is the highest amongst other industries. (Morgan 2012)

Currently, there is a lack of definitions which exist in both industry and academic research literature. However one of the simplest, "Social Customer Service (SCS), is about using social technologies to provide or facilitate customer service or support" (Clarkson 2011). This definition illustrates that the core aim is the same as mainstream customer service which is to help customers, but that this is aided through technology, specifically social media networks. The term SCS emerged around 2011 on digitally focused business blogs like Mashable and E-consultancy, and industry trade publications like Women's Wear Daily (WWD) and Drapers. These platforms have been steadily mentioning the topic since then, with heightened activity at the end of 2013. The phenomenon can be described as a "bottom up" trend, as fashion retailers have developed strategies in response to changes in consumer behavior, which in this case is using social media networks to contact brands for support, complaints, and questions (Wilson \& Blunt, 2013). Consumers are doing this primarily for speed motivations; there is a perception that social media queries will be answered faster and that news feeds will have the most up to date information. Brands have realized through negative situations that it can be a good idea to have separate SCS accounts. This is because consumer complaints and issues can "clog up" a retailer's feed, and as social media is also used as an integrated communication tool, this potentially sends out a negative image about the brand. The practice of a separate account also means the appropriate team can handle the issue, such as retail or operations for a customer service issues and marketing/PR for promotional issues. A more evolved approach to SCS can be seen by fashion brands like the aforementioned Warby Parker and Jack Threads who use dedicated accounts, monitor and measure interaction, and who claim to have a 95\% customer service rating (Retail TouchPoints, 2013).

\section{Benefits and challenges of SCS}

Figure 1 (See Figure 1 at page 246) illustrates the positives and negatives of SCS within the context of both operational and strategic management. The benefits are its access, measurability and return on investment, whilst its challenges include a consistent and appropriate tone of voice, response time, and lack of control. 


\begin{tabular}{|c|c|}
\hline Benefits & Challenges \\
\hline $\begin{array}{l}\text { - Can answer high volume tweets in event of } \\
\text { a crisis. } \\
\text { - A cohesive system can allow you to build } \\
\text { customer profiles, create an ongoing } \\
\text { documented relationship } \\
\text { - Gives a Customer Service team the ability } \\
\text { to manage their own KPI (Key Performance } \\
\text { Indicators) } \\
\text { - Customers are on the look out for companies } \\
\text { with better customer service. } \\
\text { - The spend: Social media users will spend } 21 \% \\
\text { more with companies who deliver great CS, } \\
\text { versus the general population who would only } \\
\text { spend } 13 \% \text { more. } \\
\text { - The referral: } 71 \% \text { of those who experience } \\
\text { positive social customer care are likely to } \\
\text { recommend that brand to others, compared } \\
\text { to just } 19 \% \text { of customers that don't get a } \\
\text { response } \\
\text { Change can happen quickly, easier to } \\
\text { make adjustments on-the-fly to real-time } \\
\text { intelligence }\end{array}$ & $\begin{array}{l}\text { - Companies needs a system that gives all } \\
\text { CS departments the same level of customer } \\
\text { access, and also amount of power/access to } \\
\text { promotions and special offers. i.e. Call Center } \\
\text { versus Customer Service } \\
\text { - Without a cohesive, all in one system, two } \\
\text { agents could be replying to the same customer } \\
\text { on different platforms } \\
\text { - Every CS system has different costs. Person to } \\
\text { person is becoming more costly but alienates } \\
\text { older customers, those without internet access, } \\
\text { let alone social media. } \\
\text { - Makes customer service both global and } 24 \\
\text { hour demanding, even for the small business } \\
\text { as } 50 \% \text { of Twitter users expect a response } \\
\text { within two hours } \\
\text { - International access to all platforms i.e. live } \\
\text { Chats } \\
\text { - Customer can create boycotts or protests } \\
\text { easily }\end{array}$ \\
\hline
\end{tabular}

Figure 1. Benefits and Challenges of SCS. Source: (Adapted from Sparkcentral (2013), Conversocial (2014b), Online Business (2013).

\section{Methodology}

Due to an absence of accepted theoretical frameworks, the research design for this study is qualitative and inductive in nature, and it will take a three phase exploratory approach. The first phase involves secondary research of newspaper reports, trade magazines, and market research to examine the sentiment and involvement of fashion brands to social customer service. During this phase, the top three brand who are mentioned most positively will be selected for primary research in the following stage. The outcome of this was that Burberry, ModCloth, and Next were the most prominently discussed. The second phase of the methodology will involve a content analysis of each of the three brand's main social media platforms (Facebook, Twitter, YouTube, and Pinterest). The rationale for examining these platforms specifically is that they are the most used for customer service functions. The third phase involves in-depth elite interviews with social media marketing managers. The aim of this will be primarily to indentify the motives for utilization (or otherwise) of social customer service. The elite interviewees will also be asked to describe the ways in which their brand uses social customer service. A wider sample of fashion brands that have been identified as successful in their use of social customer service from stage one will be targeted for interview. This three phase approach will allow for triangulation of 
data and will help to form an empirical framework which can be tested quantitatively in future studies. The data from phase two and three will be evaluated using thematic analysis, searching for key trends, and differences between brands.

\section{Results and discussion}

\section{Case 1. Burberry}

\section{Background}

Thomas Burberry founded the eponymous line in England, 1856, as an outdoor clothing company. Soon after, he introduced the waterproof and breathable gabardine trench coat, the mainstay of the Burberry collection. As the brand grew older, it lost its way and fell to the wayside of the fashion industry until 1997, when Rose Marie Bravo took over as CEO. She revamped the brand with an emphasis on younger, high-end customers. In 2006 Angela Ahrendts became CEO and once again turned the tide of the company, this time towards digital and social media. She, along with Chief Creative Officer Christopher Bailey, worked extensively to turn Burberry into the most digitally connected fashion brand, and many believe they have accomplished that goal. The pair focused on the likes of Nike, Apple, and Google as examples, and have devoted $60 \%$ of its ad budget to digital media (Grieve, Idiculla, Tobias, 2013). They launched media campaigns that doubled Burberry's Facebook fans and YouTube views, and tripled Twitter followers (Gallo, 2012). Burberry, "...openly admits that it has become as much a media content company as a design company because... 'it's part of the overall experience"' (Swinton, nd). Yet, the company has not devoted as much attention to its social media customer care services as it has to using social media for marketing. Stella Service rated Burberry in April 2013 as "excellent" in phone and email service, but "poor" in chat. Twitter, another Stella Services category, did not even appear on the statistics (Stella Service, 2013). So has Burberry, a pioneer and expert in social media, actually utilized it for customer service?

\section{SalesForce}

Burberry launched "Burberry World", an immersive, interactive, connected website, in 2012. It allows customers to interact with all forms of the business including heritage, music, video, and instant chat for customer service (Frontline, 2012). The company behind the "World" is SalesForce, a social media managing company that offers a suite of cloudbased marketing services (Econsultancy, 2012). Unlike Modcloth's ZenDesk, SalesForce is not used for its customer care initiatives but for its ability to link all of Burberry's social media together to provide one gigantic immersive experience no matter the platform or continent (Burberry, Salesforce). Its goal is "total integration among the company, its employees, its customers, and that all-important brand" (Burberry, Salesforce). With this in mind, it launched tailored, targeted marketing campaigns across Burberry World. It does touch upon customer service because consumers can "engage, entertain and interact", but it does not appear to handle customer care complaints or provide customer service metrics. 


\section{Digital Customer Profiles}

Burberry has managed to make personal, intimate customer service connections despite its reputation for aloofness and high-end luxury. It does this through its new store, the brainchild of CEO Angela Ahrendts. The store's goal is to bring the online experience to the physical rather than the other way around. It does this in a data-driven program called Customer 360. First, a customer inputs data on her profile including buying history, shopping preferences and fashion phobias. Once she walks into a store, RFID electronic tags are used to track her habits. These tags, embedded inside clothing, tracks what she tries on (with her permission). This data is then fed into a software platform that gathers other metrics like her Twitter history, shopping preferences, trending fashions, and past purchases. With this data in hand, a sales representative armed with a tablet can make recommendations for her, show her pictures and videos of products, or arrange for a store pick-up in another country (Soudagar, 2013). It is the ultimate in customer service: a personal shopping experience with an international luxury brand.

\section{Twitter}

Burberry has over 2,500,000 followers on its Twitter handle @Burberry. It does not respond to customers on this handle, and nearly every post has a video or picture of Burberry products/events linked to it (Moth, 2013). Burberry's dedicated customer service handle, @burberryservice, has just over 3,000 followers and is available 24 hours a day seven days a week. When customers click through the official Burberry handle to the customer service handle, it only shows one tweet in the feed explaining that this is the service handle -an excellent way to appear as though no customer complaints have occurred. In order to see the service tweets, a customer must click on the tag "All". Burberry associates respond to every message in a polite, clear, calm voice. It does not have a personality like that of ModCloth and representatives do not sign their initials. Direct messages are required to continue most conversations. From the recent tweets, it seems that customers have the most issues with phone customer service representatives but generally have excellent experiences in-store (Burberry, Twitter). It is interesting to note that while Burberry claims their service twitter handle is always available, it is not a category on their Stella Service report from April 2013 (Stella Service, 2013).

Aside from their service handle, Burberry uses Twitter as a social media campaign platform. It hosted the TweetWalk campaigns, where followers could watch behind the scenes videos moments before the models went on stage. It also branched into extended customer service by rewarding followers that congratulated the brand on one million followers with personal messages from Christopher Bailey. In the same vein, it rewarded followers who shared an image of the brand by tweeting directly to them (Moth, 2013). Unlike ModCloth, which engages users on all sorts of topics and hunts down indirect tweets, Burberry rarely engages their customers personally.

\section{Facebook Media Campaigns}

Burberry rarely uses Facebook as a customer service portal. It is a primary host of social media campaigns, like the current Burberry Acoustic (Moth, 2013). It did, however, give away free "Burberry Body" fragrances to followers that visited the site to request a free 
sample (Indvik, 2011), which is a form of customer service. Burberry also does not have a "Recent Post" section by users like Next and ModCloth do. This section lets customers post comments and complaints; Burberry has removed this potential customer service portal, maintaining a sleek, glossy Facebook page (Burberry, Facebook). Customers may still comment on photos and videos posted, not all of which are positive reviews.

\section{Other social platforms}

As the doyen of the luxury brand presence on social media, Burberry uses a plethora of other digital sites, but rarely for customer service. A notable exception is their Art of the Trench campaign, launched in 2009, which increased their site traffic by $60 \%$ (Gallo, 2012). The site allows customers to upload images of themselves wearing the Burberry trench, thereby getting their " 15 minutes of fame". This extended customer service application allows users to share their sense of style and creates an "in the know" feeling by being marketed through word of mouth, maintaining the luxury image. Thanks to this platform, Burberry's ecommerce sales grew by $50 \%$ year over year. (Grieve, Idiculla, \& Tobias, 2013)

Burberry's use of Pinterest does not include customer service, unlike ModCloth's. All of the 19 image galleries are curated by Burberry, have content from Burberry brand sites only, and do not allow outside pinners (Moth, 2013). Every board contains images Burberry products and clothing; there are no community or cultural interests involved. Here is a missed opportunity for Burberry to expand its customer care and include boards focused on the lifestyle of its customer, including travel, food, and home décor.

Unlike most brands, Burberry maintains an active Google+ site, but it is populated with mostly recycled Facebook and Twitter material. Burberry also seems to have missed a customer service opportunity here, since its campaign Burberry Acoustic would lend itself well to Google Hangouts with the musicians. (Moth, 2013)

\section{Criticisms}

The most common criticism of Burberry is that it does not engage authentically with its customers. It also does not have good ratings for its live chat service and no data for its Twitter customer service handle (Stella Service, 2013). Burberry also seems to only engage with Twitter and Facebook followers to "reward" them, which can appear aloof, condescending, and distant.

\section{Challenges}

Burberry has to create a personal rapport with customers if they want to improve their social media customer service. It will be extremely hard to do this because of its size and "luxury" status; the democratic nature of social media does not immediately translate well for luxury brands and can seem off-image. However, Burberry has already taken huge steps towards building personal relationships in-store with their new data-driven customer profile experience. Now they have to make Twitter just as personal, perhaps by signing tweets, actively seeking out twitter feeds with "Burberry" mentioned and commenting, or posting material not related directly to Burberry products. It has done a wonderful job of building a Burberry product community, but not a community that can converse 
and engage on multiple levels and depths. At the moment, it is a superficial community compared to the likes of ModCloth. Christopher Bailey sums it up nicely: "I get excited about using all of these platforms to communicate to all of our different communities around the world about what we're doing". Note that Bailey states "communicate to all" instead of "with" and talks about communicating what Burberry is doing and nothing more. It is a one-way street at the moment, but the Omnichannel of the future demands a multi-way street in customer service.

Burberry should also take advantage of customer service opportunities. They brand is very good at social media campaigns, but rarely take advantage of customer care potentials. Hiring a company like ZenDesk could be the answer, as all customer issues would be routed through one office. It would also provide Burberry with a suite of customer care platforms and assist with improving their live chat and Twitter customer service reputations through analytics and data gathering.

At the same time, Burberry has to maintain its luxury status. The balance between personal interaction and luxury goods makes a seamless, community-oriented customer service strategy more difficult than a smaller niche company's strategy. When the brand image is one of sleek aloofness, it does not make it easy to appear warm, friendly and chatty in customer service channels. Burberry will have to find a medium.

As with all brands trying to make their customer service more personal and authentic, Burberry will have the challenge of maintaining on-brand content and a consistent voice, particularly because of their large, international customer base.

\section{Evaluation of Burberry}

"Angela Ahrendts calls [the digital sphere] 'the million square foot store', suggesting that every interaction is as crucial as the next, no matter what channel" (Swinton, nd). Burberry knows this, but does not apply it to social media customer care. It is no longer enough to simply be connected to every customer; a brand has to actively engage with and create a feeling of a conversing community. Burberry World has given the customer that link to the Burberry community by creating a seamless Burberry experience, but it does not carry through to customer service. The Twitter care handle seems to handle complaints well, but there is no personal touch and no statistics for response time or rate. Burberry is a genius at capturing customer attention but does not utilize Facebook, Pinterest, or Google+ in ways that create an authentic customer service interaction with customers. It has excellent ratings in phone and email service, but poor in live chat; such a large company should be aware of these statistics and focus on correcting them. Because of its large following, international community, and luxury status, Burberry will have a challenge in creating this personal experience in the social media sphere. Creating an appropriate voice, maintaining it, and handling the vast amounts of complaints will be difficult. But Burberry has proven itself innovative and adaptable in the digital sphere; there is no reason why it could not apply that skill to its social media customer service. 


\section{Case Study 2. ModCloth}

\section{Background}

Founded in 2002 by Eric Kroger and Susan Greg Kroger the summer before they attended Carnegie Mellon University, ModCloth has grown from a dorm room operation to a 100 million-dollar giant with three U.S. headquarters in Los Angeles, Pittsburgh, and San Francisco (Fenzi, 2013). It offers clothes and home goods in vintage, thrifty, and retro styles. In 2009 it made the list of America's Fastest Growing Retailers, and in 2013 it was named second in Fast Company's list of 2013's Most Innovative Companies, just behind fellow ecommerce site Nasty Gal (Kratochwill, Lidsky, \& Rhodes, 2013). The company recently completed a $\$ 25$ million fundraising campaign, launched a private label, and has a total venture funding of $\$ 44.4$ million (Soudagar, 2014). The drive behind this incredible growth is ModCloth's use of social media and consistent voice. It is well known and often cited for its creative use of multiple platforms to engage a like-minded community in authentic conversations about all sorts of topics, not just fashion. Stella Service rated ModCloth as "excellent" in customer service in November 2013; the company received "outstanding" in all four categories, including phone, email, chat and Twitter (Stella Service, 2013). It has an average customer service rating of $94 \%$, well above the industry standard of $82 \%$ (Zendesk, nd). ModCloth's target market is the Millennial, $80 \%$ of whom use social media several times a day, and 95\% have Facebook (Stadd, 2013). In the vast space of the internet, ModCloth has managed to break through the noise and link its community across all social platforms, resulting in huge sales, high engagement and a reputation for excellent customer service. In an industry that ignores $70 \%$ of complaints, ModCloth has created a customer care niche for itself (Stillman, 2012). So just how does ModCloth utilize social media for customer service in a way that puts it above the rest of the ecommerce world?

\section{Hired a Social Media Manager}

ModCloth took the ingenious step in 2011 of hiring a social media managing company to link all of its online platforms and route them through one channel. With $67 \%$ of customers using multiple channels when making a purchase, $87 \%$ said brands have to work on making the shopping experience seamless (Peart, 2013), having all customer care issues funneled into one area improves efficiency. ModCloth choose ZenDesk, a cloud-based company that also offers analytics and reporting (Stillman, 2012). ModCloth specifically hired ZenDesk's Customer Support program and has 41 agents dedicated to customer care (Zendesk, nd). A social media manager like ZenDesk removes the question of which tickets have been answered, how quickly were they answered, which representative is taking care of a client, what channel is this client using, and has anyone been forgotten along the way. Thus far, ZenDesk has serviced over 113,000 ModCloth customers and issued over 270,000 tickets. It integrates ModCloth's dedicated customer care Twitter handle, @ModCloth_ Cares, with its email and web channels, increasing response time. Equally important, ZenDesk provides the data behind the service, revealing the team's response time, ticket volume, and support coverage gaps. With this data, ModCloth can target specific areas when coaching representatives, make changes, plan ahead, and improve their overall 
methods. A ModCloth representative can also search for a tag quickly thanks to ZenDesk's data collection, drastically reducing customer frustration and wait times. ZenDesk also uses pre-defined responses called "macros" to respond to common customer service issues like returns to reduce response time. Additionally, ZenDesk provides their customers with apps like Sprout Social for social media monitoring, LiveChat for customer support, and GoodData for performance analytics, all of which ModCloth utilizes (Zendesk, nd).

The proof of ZenDesk's performance is in the data: ModCloth saw a 20\% increase in agent productivity, 457 tickets solved per agent per month, $96 \%$ of all tickets answered on first touch, and a $20 \%$ reduction in support costs. It also decreased its response time from 37 hours to 7 hours within 7 months, with an average time of 5.3 hours. Thanks to ZenDesk, ModCloth can easily track and handle high volumes of customer complaints.

\section{Utilizes all platforms that fit the brand}

Aaron Lee of the blog "Ask Aaron Lee" sums up ModCloth's online presence perfectly: ModCloth "...connected all of these platforms together to build a massive office suite... I wouldn't say that they are mostly active on Twitter or Facebook, but instead I'll simply say that they are online" (Lee, nd). ModCloth uses Twitter, Facebook, Instagram, tumblr, Pinterest, and anything else that its customer uses. As ModCloth's Social Media representative Alicia Barnes says, "We believe in meeting the customer and talking with her wherever she is!” (Loomba, 2012). This also means discriminating; ModCloth does not use platforms and apps that its customers do not use. Most importantly, ModCloth engages the customer on every platform in an interesting, authentic way, whether it is a customer care concern or a comment on music.

On Twitter, ModCloth has their official @ModCloth handle along with a customer care handle, @ModCloth_Cares. The official handle's followers grew from 19,000 to 110,000 in the last 2 years, which is about the time ModCloth hired ZenDesk (Carsen, 2013). The goals of ModCloth on Twitter, according to social media manager Martha Smith, is to "engage, delight and reward its online community". It, "Communicates the ModCloth message and personality to new customers and serves as an efficient customer service tool" (Carsen, 2013). ModCloth wants the customer to feel like they are talking to a personality and having an intimate conversation with someone, just as though they were speaking in person. It replies to all tweets to their customer care handle. ModCloth is also famous for their indirect Twitter responses. Representatives will search for customer feed tweets and respond to them with the same friendly, engaging voice, as Alyssa Adkins discovered to her delight on Social Media Today. Adkins felt special, singled out, saying that ModCloth sees "the customer not as a generic clump of the masses, but as individuals with a desire to feel special" (Adkins, 2013). This sentiment meshes perfectly with the next generation of social media customer care that demands the personal touch. It also generates sales: as Adkins explains, "by being authentic and invested in me as a consumer, well, it's got me feeling pretty smitten" (Adkins, 2013).

In an additional layer of customer support, ModCloth offers free use of an online stylist. As Aaron Lee explains in his blog post, a customer can post on her feed that she does not know how to wear a ModCloth top and within minutes ModCloth will respond, offering her use of the stylist. 
ModCloth also has an open Facebook where customers can comment and log complaints. Here, thanks to ZenDesk streamlining customer complaints, ModCloth is free to engage the customer on other, deeper levels of care. It shares hobbies, personal videos from its YouTube channel, quotes, and beautiful photos. To spark interest and conversation, it asks questions of its community.

ModCloth's Pinterest account is vibrant, active, and includes all aspects of the ModCloth customer's lifestyle. It includes 19 boards that branch into customer service by providing ideas for gifts, home decorating items, art galleries and literature. Unlike other brands like Burberry, ModCloth pins images from outside sources, not just the ModCloth website or handles. It has more followers than Burberry and Next combined: 2,221,148, despite having the least pins at 3,856. These numbers show a remarkable attachment and investment of consumers. It also demonstrates that ModCloth follows a policy of quality over quantity, and that creating content around outside interests and hobbies pays off. Youtube is another sphere of care that does not deal with complaints, but with a more constructive form of customer service. ModCloth's channel offers make-up and vintage hairstyle tips, on-target DIYs like sewing lace patches onto stockings, and behind the scenes videos.

In the same type of customer care as Youtube, ModCloth uses Google Hangouts to engage with celebrities that its community would like. For example, pop culture icon Neyla Pekarek of the indie band the Lumineers recently hosted a Hangout.

\section{Crowdsourcing}

Crowdsourcing makes the consumer feel like a company is listening to her. ModCloth explains on its website that it wants to make fashion democratic by bringing the design choices to the consumer directly. This engages the customer on an entirely new level and must be included in customer service data because it lets the customer have a say in what the store sells. ModCloth has its "Be the Buyer" program, which lets customers vote and comment on new trade show items and prototypes (Lee, nd). It also hosted the campaign "Make the Cut", during which people voted on submissions made by the ModCloth community; they received 1,900 submissions, over 10,000 votes, and mass-produced the winning design. A caveat to crowdsourcing is the size of the company; it is easier for smaller niche companies to crowdsource than large department stores or luxury brands.

\section{Apps}

ZenDesk provides ModCloth with a number of customer care apps, including LiveChat, a program that opens when viewers click to chat on their Customer Info Center. The program asks for a name, email address, if the customer is chatting from a mobile device, and if the customer has shopped with ModCloth before. According to ZenDesk, 52\% of customers expect a response to a social media complaint within one day, as do $75 \%$ of customers emailing complaints. ModCloth has provided an instantaneous solution to the problem through LiveChat, offering customers the potential of having their issue resolved within minutes of it occurring. ModCloth also asks people in its Twitter feed to go to 
LiveChat to resolve issues, unlike companies like Next and Burberry that request private messages. Again, this gives the customer a sense of real-time problem solving. It is also another layer of intimacy, equal to chatting on the phone.

ModCloth is currently creating a Mobile app for its website (Loomba, 2012). It is still a work in progress, but that does not mean ModCloth will let this social media opportunity go to waste; it is asking customers to give their input on the app and will continue to improve it based on customer feedback. Eventually the app will allow users to browse, shop, leave reviews, and participate in crowdsourcing activates.

Sprout Social, an app provided to ModCloth by ZenDesk, is a social media managing tool that includes features like scheduled publishing, a single inbox for all social platform complaints, analytics, and monitoring social feeds for mentions of the brand. It also allows customer representatives to coordinate who is handling which tasks, and the ability to bring all of the above to a mobile platform (Sprout Social). ModCloth uses it primarily for social media monitoring, which allows it to find those indirect Tweets for which it is famous.

\section{Consistent voice}

$37 \%$ of customers want to speak to the same representative no matter what channels they are using. ModCloth has heard the customer's cry for a seamless experience and responded with the ModCloth "voice". This "voice" retains the same tone and style across all platforms and is friendly, helpful, and casual. To give the customer a personal experience, representatives sign their initials, use colloquial phrases, smileys, and exclamation points, and include words like, "woo-hoo!" and "oh no," which combine to make a very natural, easy-going conversation. As the introduction stated, the idea of the "omnichannel" requires that customers be able to carry a conversation from one platform to the next seamlessly; this is much easier when dealing with the same representative. Between the named representative and ZenDesk's tagging and linking abilities, ModCloth customers are virtually guaranteed a seamless customer care experience no matter which platform they use.

\section{Challenges}

ModCloth's Social Media Manager Martha Smith explained in an interview for Sprout Social that one of ModCloth's biggest challenges is balancing a personal voice with brand messaging on platforms like Twitter. As the company grows within the public social sphere so does the potential for a PR disaster. Representatives cannot use inappropriate wording or promise something to a customer and then never deliver. To prevent such an event, ModCloth has "simple but emphatic" training for representatives on how to communicate in public channels (Carsen, 2013). Of course, no matter the amount of training, a textual misstep is always a possibility; with so many eyes on the ever-growing ModCloth combined with human error, it will be a challenge to avoid such an event.

\section{Evaluation of Modcloth}

ModCloth weaves a seamless, authentic, personal customer service experience across multiple social media platforms. The use of ZenDesk as a third-party social media manager streamlines customer complaints and provides useful metrics. By utilizing all social media platforms and apps that fit its customer, ModCloth engages its customers at every turn 
and provides them multiple outlets for complaints and comments. Crowdsourcing lets the customer feel like part of the team while a consistent, personal voice generates the next-gen customer care service people expect. $75 \%$ of customers say they would return to a company that provided a good customer care experience, and with its $94 \%$ customer satisfaction rating, ModCloth customers will not just come back but also recommend it to friends (Peart, 2013). The ModCloth "voice", individual representatives that respond to every single comment, and tweet no matter the subject and the sharing of non-fashion related items on Facebook and Google Hangout, create a depth of customer care that few brands can match. Its sky-high Pinterest followers and low amount of pins speaks to a consumer attachment to the community not just for the clothes, but for all the services ModCloth can provide. The ModCloth community is invested in the brand not just for clothes, but as a way of life. In the future ModCloth will have the challenge of balancing its brand voice with representatives' personal voice. But with training already in place to prevent a PR scandal and a stellar record of social media customer service, ModCloth appears to have cemented its place at the top of the ecommerce sites.

\section{Case Study 3. Next}

\section{Background}

Next is the second largest clothing retailer in the UK; it operates 540 stores in the UK and Ireland along with over 200 internationally, and employs 54,507 people. In 2013, the company grossed 3.5 billion Euro and topped the Christmas sales charts with a $12 \%$ surge in sales, putting it ahead of Marks and Spencer. Along with the brick and mortar stores, Next operates Next Directory, originally a mail-order catalogue that is now a thriving online shop with 3.3 million active customers in 2013 spread across 60 countries (Butler, 2014). At the end of November 2013, it was named the "Best UK Retailer for Social Media Customer Service" (Next annual report, 2013). IMGROUP also conducted a study of the top ten largest UK retailers and their activity in the social media sphere, specifically Facebook, Twitter, Pinterest, and Google+ (Farrelly, 2013). The study found Next to be the best in the categories of response rate, response time, and number of followers. In light of this prestigious award, the question arises: what social media customer service practices put Next ahead of its competitors?

\section{Quick Response Time}

The social media manager website ZenDesk reported in their Omnichannel Customer Service Gap Report that $89 \%$ of customers, when asked about "the most important aspects of the customer service experience". replied "speed of response". An identical percentage responded "speed of resolution". In the same study 52\% of consumers responded that they expected a reply to a social media request within one day (ZenDesk, 2013). As the introduction of this paper explained, the "omnichannel" idea now dictates that companies create a seamless, intuitive customer experience across all channels of communication, including customer service. This requires near-instant, real-time response to customer complaints and comments on social media platforms like Twitter and Facebook. In this 
area, Next surpassed its rivals. In a comparative study done by eModeration using data from the website Social Bakers, Next appeared in the number two spot within a group of ten other U.K. retailers and one U.S. retailer. It had 1,208,028 fans and a response time of 23 minutes, by far the fastest in the group. The next quickest responder was Tesco Customer Care at 81 minutes with only 75,904 fans. Despite the higher volume, Next had a significantly lower response time (Fisher, 2013). In the IMGROUP study, Next had a response time average of 28 minutes (Farrelly, 2013). According to eModeration and Social Baker, the industry standard for response time is 1,542 minutes, putting Next well above average.

\section{High response rate}

A quick response time means nothing without a high response rate. In a study done by Maritz Research and evolve-24, $49 \%$ of consumers expected the company to read a tweeted complaint (2012). Yet only $29 \%$ received a response, and $83 \%$ of those said they "loved" or "liked" receiving the response. In the group that did not receive a reply, $86 \%$ would have appreciated a reply. Once again, Next trumped its competitors in response rates. The IMGROUP study found that Next had a 92\% response rate, while the eModeration comparison study found it had a nearly-perfect $96.94 \%$ response rate. The company with the second highest response rate was Boots UK with $95.72 \%$, but only 479,411 fans compared to Next's 1,208,028. EModeration listed the industry standard response rate as $63 \%$ - a number Next handily surpassed.

\section{Presence on multiple social platforms}

In the Twitter sphere, the brand operates the handles @nextofficial and @nexthelp, a handle devoted solely to customer service requests. Once a customer comments on the feed, Next requests a private message to further discuss the issue. The Twitter care voice is polite, calm, and reassuring. On its official handle the voice becomes friendlier, excited at times, and always enthusiastic.

Aside from its presence on Twitter, Next also has a strong Facebook presence. It allows followers to comment openly on its main page, including customer service complaints. Because there is the option to not allow this open channel, Next's use of it makes it seem open, friendly, and accessible. Much like its official Twitter feed, the posts on Facebook are always on-product but with a fun, casual twist that touch on other hobbies and interests of its customers. Next tries to connect with the customer by sympathizing with them and offering them solutions, as in this recent post to its Facebook page: "Finding it hard to get back to the gym after the party season? You're not alone! Though some new kit could be all it takes to get you back on track. Here's a few of our fave fitness essentials..." This transfers the simple posting of a fitness picture montage into the realm of customer service.

Pinterest is a strong site for Next, with 47 boards and 7,504 followers. It only has six "Likes", but considering Burberry has zero, one cannot use the Likes as a measure of success. Because Next is a large department store, it has an ample supply of potential board topics, including one called "Services From Next". Yet, despite the high number of boards, Next only has 7,504 followers for its 47 boards, compared to over 2 million followers for ModCloth's 19 boards. 
Next also maintains an active Google+ account that has fresh content and the same warm, friendly tone of voice. Again, it maintains a customer service atmosphere by offering products for losing weight, gift ideas, and suggestions for children's clothes.

The YouTube channel for Next is not updated regularly, but it contains very informative and in depth videos. The topics range from branding and advertising to key trends to Christmas gift guides. Once again Next has taken advantage of a customer service opportunity.

\section{Friendliness}

The Zendesk Omnichannel study listed $82 \%$ of consumers responding "friendliness of representative" as the most important aspect of the customer care experience. Next responses on Twitter and Facebook are friendly, polite, occasionally personalized, and always professional. Their official handle is as chatty as a friend: "Does your man fancy himself as a bit of a James Bond? Well at least he can dress the part!" (Next, Twitter). Next, despite the lack of individual sales representative signatures on comments, adds personality through smiley faces on Twitter posts and takes the time to reply to customer responses that are not direct questions or demands.

\section{Areas of improvement}

Next does not explicitly state on its Facebook page the times during which it will reply to comments; providing that information can give consumers a sense of when to expect replies and subdue anger at not having received one in the wee hours of the morning. It does, however, list its customer service twitter handle as " $24 / 7$ ". Next could also post guidelines concerning consumer behavior within comments and complaints, including whether or not it will reply in international languages. Next also does not sign its comments with the name of the individual representative replying, which takes aware from engagement and interaction. (Fisher, 2013)

\section{Challenges}

Next has the response rate, response time, and friendliness required for excellent customer service, but it does not have the same depth of engagement and interaction as other brands. It lacks the personal touch of an individual customer service agent replying to a consumer, an agent that the consumer can then ask for again if there is a problem further down the road. The Omnichannel described by Zendesk requires this level of personalization to function smoothly and to transfer conversations from one channel to the next, including phone and email. It will be a challenge for Next, the second largest clothing retailer in the U.K., to provide such a close, personal experience for its huge number of customers.

A personalized experience for a Next customer, however, is much more difficult to achieve than a ModCloth customer. A niche market company can reliably maintain the same tone and style throughout its social media platforms and feel confident that it is responding appropriately to its customers. A giant retailer like Next has dozens of segments of customers, each with their own preferred tone and style. It would require a large team, many resources, and a great deal of time to personalize each message according to the customer's preferred tone. It is also much more difficult for Next to follow and track each 
customer's likes, reviews, product views, and comments across all platforms than it is for a smaller company like ModCloth due to sheer volume.

Next also utilizes only a fraction of the potential customer service portals. While Facebook and Twitter are large portions of the customer care cycle, it could expand by signing up with a service like Zendesk to manage its social media customer service and provide a more intuitive experience for the customer. Companies like Conversocial could help them track their conversations and manage the data received so they can create a personalized experience for individual customers. Partnering with a social media managing company would link all of their customer care services into one portal, putting Next one step closer to the "omnichannel".

\section{Evaluation of Next}

Next recognizes that most of its consumers now reside and interact with brands online. It utilizes three main channels of social media -Twitter, Facebook, and Pinterest- to stay in contact with their customers and ensure they are receiving the best possible service. They do this through an old-school method of constant, consistent communication within the technology sphere. It contains no frills, no fancy high-tech apps, or next-gen software; it's simply timely, quality service no matter the volume of comments. Quick response times, high response rates, and friendliness in interactions set it apart from and above its peers. Areas of improvements include posting explicit times of reply on Facebook, posting a behavior guideline, and requiring a representative to sign their comments. The challenges lie in crafting a seamless, individualized customer experience across their social media platforms. This could be achieved by having customer service representatives sign their comments so that customers can request them by name, linking together all of the customer care platforms through a company like Zendesk, collecting and analyzing data through a company like Conversocial, applying that data to create individualized experiences, and devoting time and resources to responding to customers in different tones and styles.

\section{References}

30 Under 30: Art and style. (no date). Forbes. Retrieved from http://www.forbes.com/ pictures/mkl45jfhj/eric-koger-and-susan-gregg-koger-28-fashion-retailers-4/

Adkins, A. (2012, June 19). ModCloth: A rad (and obvious) social media strategy. Social Media Today. Retrieved from http://socialmediatoday.com/alyssa-adkins/1544001/ modcloth-social-media-strategy

Brown, E (2010). Working the crowd: Social media marketing for business. London: British Computer Society.

Burberry. Twitter. Retrieved from https://twitter.com/BurberryService/with_replies

Burberry. Facebook. Retrieved from https://www.facebook.com/burberry

Burberry to use social data and RFID to build customer profiles in-store. (2012, September

20) Econsultancy. Retrieved from http://econsultancy.com/nma-archive/47228-burberryto-use-social-data-and-rfid-to-build-customer-profiles-in-store 
Burberry builds deeper customer connections, from the runway to the retail store. (no date) SalesForce. Retrieved from http://www.salesforce.com/customers/stories/burberry.jsp

Butler, S. (2014, January 3). Next emerges as big Christmas winner with sales up $12 \%$. The Guardian. Retrieved from http://www.theguardian.com/business/2014/jan/03/nextchristmas-winner-sales-clothing-retailer

Carsen, N. (2013, May 21). JetBlue and ModCloth share three policies to prevent social media disaster. Sprout Social. Retrieved from http://sproutsocial.com/insights/twittersupport-policies/

Casserly, M. (2013, July 23). ModCloth hits 100 million in revenue, gives social all the credit. Forbes. Retrieved from <http://www.forbes.com/sites/meghancasserly/2013/07/23/ modcloth-hits-100-million-in-revenue-gives-social-all-the-credit/

Comprehensive features for social business. (no date) Sprout Social. Retrieved from http:// sproutsocial.com/features

End of year report. (2014). Conversocial. Retrieved from http://www.conversocial.com/ blog/-end-of-year-report-the-social-customer-service-year-in-review\#.UtjaWtJdWSo

Farrelly, J. (2013, November 29). Study finds Next is best UK retailer for social media customer service. Digital Marketing Institute. Retrieved from https://digitalmarketinginstitute.com/ blog/study-finds-next-best-uk-retailer-social-media-customer-service

Fenzi, F. (2013, April 23). ModCloth's key strategy: Be a friend to customer's first. Inc. Retrieved from http://www.inc.com/francesca-fenzi/modcloth-knows-how-to-hang.html Fisher, T. (2013, May 28). Be smart. Be respectful. Be human. Retail social customer service case studies: Best Buy, M\&S, Tesco, Next and Boots. eModeration. Retrieved from https:// www.emoderation.com/social-media-customer-service-case-studies

Clarkson, D. (2011, January 10). Defining customer service will be a moving target. Forrester Research. Retrieved from http://blogs.forrester.com/diane_clarkson/11-01-10defining_customer_service_will_be_a_moving_target_in_2011

Fiorletta, A. (2013, September 6). Jacks Threads weaves social media into customer service strategy. Retail Touchpoints. Retrieved from http://www.retailtouchpoints.com/retail$\mathrm{crm} / 2857$-jackthreads-weaves-social-media-into-customer-service-strategy

Gallo, D. (2012, August 14). Luxury brand Burberry moves beyond the tartan. Social Media Week. Retrieved from http://socialmediaweek.org/blog/2012/08/luxury-brand-burberrymoves-beyond-the-tartan/\#.Uscrc3-4s-U

Grieve, J., Idiculla, A., \& Tobias, K. (2013, February 3). Entrenched in the digital world. Business Today. Retrieved from http://businesstoday.intoday.in/story/burberry-socialmedia-initiative/1/191422.html

Henning, K. (2012, August 13). The social circle: A window to a designer's soul. Women's Wear Daily (WWD). Retrieved from http://www.wwd.com/media-news/digital/the-socialcircle-a-window-to-designers-souls-6148201

Indvik, L. (2011, August 19). Burberry brings fragrance sampling campaign exclusively to Facebook. Mashable. Retrieved from http://mashable.com/2011/08/19/burberry-bodyfacebook/

Indvik, L. (2011, September 21). Burberry's evolving role as a media company. Mashable. Retrieved from http://mashable.com/2011/09/21/burberry-media-fashion-company/ 
Kaplan, A.M. and Haenlein, M. (2011). Two hearts in three-quarter time: How to waltz the social media/viral marketing dance. Business Horizons, (54)3, 253-263.

Kietzmann, J.H., Hermkens, K., McCarthy, I.P., \& Silvestre, B.S. (2011). Social media? Get serious! Understanding the functional building blocks of social media. Business Horizons, (54)3, 241-251.

Kratochwill, L., Lidsky, D., \& Rhodes, M. (2013, February 11). Most innovative companies 2013. Fast Company. Retrieved from http://www.fastcompany.com/most-innovativecompanies/2013/nasty-gal-modcloth-styleseat-science-snapette-birchbox-ahalife

Lee, A. (no date) How @Modcloth is dominating social media. [Web log comment]. Retrieved from http://askaaronlee.com/modcloth-social-media/

Loomba, A. (2012, August 15). Exclusive interview with ModCloth's social media team. Thoroughly Modern Marketing. Retrieved from http://www.thoroughlymodernmarketing. com/exclusive-interview-with-modcloths-social-media-team/

Maritz Research and evolve24- Twitter Study. (2011, September) Maritz Research. http://www. maritzresearch.com/ /media/Files/MaritzResearch/e24/ExecutiveSummaryTwitterPoll. ashx

ModCloth. Pinterest. http://www.pinterest.com/modcloth/

MODCLOTH: Striving to be the best e-retail service center on the planet. (no date).ZenDesk. Retrieved from http://www.ZenDesk.com/why-ZenDesk/customer/modcloth

Morgan, V. (2012). SCS A Customer Checklist. Conversocial. Retrieved from http://www. conversocial.com/blog/-end-of-year-report-the-social-customer-service-year-in-review\#. UtjaWtJdWSo

Moth, D. (2013, June 12). How Burberry uses Facebook, Twitter, Pinterest and Google+. Econsultancy. Retrieved from http://econsultancy.com/blog/62897-how-burberry-usesfacebook-twitter-pinterest-and-google

Next. Facebook. Retrieved from https://www.facebook.com/nextonline

Next. Google+. Retrieved from https://plus.google.com/+next/posts

Next. YouTube Retrieved from http://www.youtube.com/user/nextshopping

Next. Pinterest Retrieved from http://www.pinterest.com/nextofficial/

Next. Twitter Retrieved from https://twitter.com/nextofficial

Next annual report: Business overview. (2013, January). Next Plc. Retrieved from http:// www.nextplc.co.uk/about-next/business-overview.aspx

The Omnichannel Customer Service Gap. (2013, November) ZenDesk. Retrived from http://cdn.zendesk.com/resources/whitepapers/Omnichannel-Customer-Service-Gap.pdf Peart, N. (2013, November 25). 2014: The year of Omnichannel customer service. ZenDesk. Retrieved from http://www.ZenDesk.com/blog/omnichannel-2014

Social Media Pays off for Burberry, as Profits Rise 21\%.(2012, January 17) The Frontline. Retrieved from http://www.v3.co.uk/v3-uk/the-frontline-blog/2139460/social-mediapays-burberry-profits-rise-21-cent

Soudagar, R. (2013, October 28). How Fashion retailer Burberry keeps customers coming back for more. Forbes. Retrieved from http://www.forbes.com/sites/sap/2013/10/28/howfashion-retailer-burberry-keeps-customers-coming-back-for-more/

Stadd, A. (2013, November 19). Millennials, fashion and social media. All Twitter. Retrieved from http://www.mediabistro.com/alltwitter/millennials-fashion-social-media_b51831 
Stillman, J. (2012, December 12). Fix your customer service. Inc. Retrieved from http:// www.inc.com/jessica-stillman/how-modcloth-solved-its-customer-service-problem.html

Stella Service (2013). Burberry. Retrieved from http://www.stellaservice.com/profile/ Burberry.com/

Stella Service (2013). ModCloth. Retrieved from http://www.stellaservice.com/profile/ modcloth.com/

Swinton, J. (no date). How Burberry's digital strategy is boosting brand value. The Guardian. Retrieved from http://www.theguardian.com/media-network/partner-zone-brand-union/ burberry-digital-strategy-brand

Teachout, E. (2013, February 11). Avoid these 5 social media customer service blunders. Online Business. Retrieved from http://onlinebusiness.volusion.com/articles/avoid-these5-social-media-customer-service-blunders/

Weinburg, B. \& Pehlivan, E. (2011). Social spending: Managing the social media mix, Business Horizons, 54(3), 275-282.

Wilson, C. \& Blunt, M. (2013). Delivering effective social customer service: How to redefine the way you manage customer experience and your corporate reputation. Wiley: London

Resumen: La tecnología digital ha cambiado la forma de las marcas de moda se comunican con los consumidores y del mercado de sus productos. Por otra parte, el auge de las plataformas de medios sociales en los últimos años ha ayudado a hacer este diálogo más atractivo, convocando a millones de nuevos consumidores a comprometerse con las marcas a nivel personal (PEW, 2013). Un reciente informe de Drapers (2013) sobre la innovación en el mercado del retail en moda, sugiere que el $52 \%$ de las empresas de la moda están utilizando los medios sociales para la interacción con el cliente y la gestión de las relaciones. El objetivo de esta investigación es explorar el uso de los medios de comunicación social para el servicio al cliente. En primer lugar el estudio identificará las razones por las cuales las marcas de moda están utilizando esta plataforma y en segundo lugar, se examinará cómo las marcas las están utilizando. Las empresas que son líderes en este espacio son en su mayor parte empresas de dedicación exclusiva estadounidenses. Como ejemplo, Warby Parker la innovadora marca de anteojos ha estado respondiendo a los problemas de servicio al cliente a través de You Tube clips que actualmente reciben más de 100 visitas (Mashable, 2013). Uno de los grandes retos, y una oportunidad al mismo tiempo, es que los consumidores utilizan las redes sociales para quejarse de los problemas de servicio al cliente (Brandwatch, 2013). ASOS abrió las cuentas de Facebook y Twitter "Estamos aquí para ayudar" para permitir que sus otros canales sociales sean utilizados con fines de relaciones públicas y comunicación minimizando así el contenido negativo en ellos (Bauer, 2013). Conversocial (2013) es un proveedor de atención al cliente especialista en medios sociales, que ha medido que el monitoreo y la respuesta efectiva en el servicio al cliente en redes sociales pueden tener un retorno directo sobre la inversión. Debido a la ausencia de marcos teóricos asociados, el presente estudio adopta un enfoque cualitativo, utilizando fuentes secundarias, el análisis de contenido de las plataformas de medios sociales y entrevistas en profundidad con representantes de marcas de moda con el fin de cumplir el objetivo de la investigación. 
Palabras clave: redes sociales - servicio al cliente - tecnología - moda - venta al por menor - digital - modelo de negocio - diferenciación - estrategia de marca - comunicación.

Resumo: A tecnologia digital mudou a forma das marcas de moda se comunicam com os consumidores e do mercado dos seus produtos. Por outro lado, o auge das plataformas de meios sociais nos últimos anos ajudou a fazer este diálogo mais atrativo, convocando a milhões de novos consumidores a se comprometer com as marcas a nível pessoal (PEW, 2013). Um recente informe de Drapers (2013) sobre a inovação no mercado retail em moda, sugere que o $52 \%$ das empresas de moda estão usando as redes sociais para a interação como o cliente e a gestão das relações. O objetivo desta pesquisa é explorar o uso dos meios de comunicação social para o serviço ao cliente. Em primeiro lugar o estudo identificará os motivos por os quais as marcas de moda estão utilizando esta plataforma e em segundo lugar, se examinará como as marcas as utilizam. As empresas que são líderes neste espaço são em maioria empresas de dedicação exclusiva estadunidenses. Por exemplo, Warby Parker, a inovadora marca de óculos responde aos problemas de serviço ao cliente através de You Tube clips que atualmente recebem mais de 100 visitas (Mashable, 2013). Um dos grandes retos, e uma oportunidade ao mesmo tempo, é que os consumidores utilizam as redes sociais para queixar-se dos problemas de serviço ao cliente (Brandwatch , 2013). ASOS abriu as contas de Facebook e Twitter "Estamos aqui para ajudar" para permitir que seus outros canais sociais sejam utilizados com fines de relações públicas e comunicação minimizando assim o conteúdo negativo neles (Bauer, 2013). Conversocial (2013) é um fornecedor de atenção ao cliente especialista em meios sociais, que mediu que o monitoramento e a resposta efetiva no serviço ao cliente em redes sociais podem ter um retorno direto sobre a inversão. Devido à ausência de quadros teóricos associados, este artigo adota um enfoque qualitativo, utilizando fontes secundarias, a análise de conteúdo das plataformas de meios sociais e entrevistas em profundidade com representantes de marcas de moda com o fim de cumprir o objetivo da pesquisa.

Palavras chave: redes sociais - serviço ao cliente - tecnologia - moda - venda ao retalho digital - modelo de negócio - diferenciação - estratégia de marca - comunicação. 